\title{
ABUNDANCE AND DIVERSITY OF AMMONIA-OXIDIZING BACTERIA IN RELATION TO AMMONIUM IN A CHINESE SHALLOW EUTROPHIC URBAN LAKE
}

\author{
Shanlian Qiu ${ }^{1,2}$; Guoyuan Chen ${ }^{1,2}$; Yiyong Zhou ${ }^{1 *}$ \\ ${ }^{1}$ Institute of Hydrobiology, Chinese Academy of Sciences, 7 Donghu Nan Road, Wuhan, Hubei 430072, China; ${ }^{2}$ Graduate School \\ of the Chinese Academy of Sciences, 19 Yuquan Road, Beijing 100049, China.
}

Submitted: February 11, 2009; Returned to authors for corrections: May 01, 2009; Approved: July 24, 2009.

\begin{abstract}
The measures of most-probable-number and restriction fragment length polymorphism analysis were used to analyze the abundance and diversity of ammonia-oxidizing bacteria in sediment of a Chinese shallow eutrophic urban lake (Lake Yuehu). Among the 5 sampling sites, ammonia concentration in interstitial water was positively proportional not only to the content of organic matter, but also to ammonia-oxidizing bacteria numbers (at a magnitude of $10^{5}$ cells $\mathrm{g}^{-1}$ dry weight) in sediment significantly. Furthermore, the diversity of ammonia-oxidizing bacteria were determined by means of PCR primers targeting the amoA gene with five gene libraries created and restriction pattern analysis. The 13 restriction patterns were recorded with 4 ones being common among all sampling sites. The 8 restriction patterns including 4 unique ones were found at the site with the highest $\mathrm{NH}_{4}{ }^{+}$concentrations in interstitial water, while, there were only common patterns without unique ones at the site with the lowest $\mathrm{NH}_{4}{ }^{+}$concentrations in interstitial water. Phylogenetic analysis showed that the amoA fragments retrieved belong to Nitrosomonas oligotropha \& ureae lineage, $N$. europaea lineage, $N$. communis lineage and Nitrosospira lineage, most of which were affiliated with the genus Nitrosomonas. The $N$. oligotropha \& ureae-like bacteria were the dominant species. Thus, the abundance and diversity of sediment AOB is closely linked to ammonium status in eutrophic lakes.
\end{abstract}

Key words: Ammonia-oxidizing bacteria, Abundance, amoA, Diversity.

\section{INTRODUCTION}

Nitrification, defined as the oxidation of ammonia to nitrate via nitrite, is a key process of the nitrogen cycling in freshwater lakes. The former is the rate-limiting step (31), which is mediated by the ammonia-oxidizing bacteria (AOB). Therefore $\mathrm{AOB}$ are of great ecological significance in freshwater lakes.

Ammonia is the essential energy source for the AOB that can adapt to a broad range of ammonia concentrations in the diverse environments, as reflected by different affinity constants for ammonia. On the other hand, ammonia is a toxic compound for AOB. Consequently, their succession and colonization in different systems requires tolerance of increasing ammonia concentrations (20). So, ammonia is one of the most important factors, influencing the distribution patterns of $\mathrm{AOB}(19,37,38,39)$, and its accumulation may occur in eutrophic lakes with the concentration being up to 4 $\mathrm{mg} \mathrm{l}^{-1}$ in Onondaga Lake (11). The ammonia concentrations in 33 Chinese lakes ranged from $0.358-1.295 \mathrm{mg} \mathrm{l}^{-1}$ on average (49). However, its linkage to AOB was inadequately studied.

*Corresponding Author. Mailing address: Institute of Hydrobiology, Chinese Academy of Sciences, 7 Donghu Nan Road, Wuhan, Hubei 430072, China.; Phone: +86-27-68780709 / Fax: +86-27-68780709.; E-mail: zhouyy@ihb.ac.cn 
Traditionally, the abundance and population structure of AOB were investigated by cultivation-dependant methods. To quantify $\mathrm{AOB}$, the most probable number (MPN) technique was often used. However, different media may produce different results (1), since some media were unfit for the growth of some AOB under special conditions in nature due to unsuitable ammonia concentration, salinity, or $\mathrm{pH}$ value (20). Therefore, the optimum medium (33) was chosen for AOB counting in lake sediments.

Molecular techniques have been allowed to obtain reliable information on the bacterial diversity in different environments $(22,42)$. The amoA gene coding for the catalytic subunit of ammonia monooxygenase reported by McTavish et al. (24) has emerged as a useful target for population studies on AOB in nature $(5,25,34,43,50)$. In freshwater environments, molecular analysis of $16 \mathrm{~S}$ rDNA and $a m o A$ genes demonstrated that the majority of AOB belong to $\beta$ subclass of the Proteobacteria including members of the genera Nitrosomonas (as well as Nitrosococcus mobilis) and Nitrosospira (as well as Nitrosolobus and Nitrosovibrio) (15, $41,44)$. Furthermore, the natural diversity of AOB in various environments has extensively been studied by comparative sequence analysis of environmental amoA clones. Consistent with the $16 \mathrm{~S}$ rDNA-based AOB diversity surveys, most amoA clones obtained are affiliated with 7 lineages defined by cultured AOB. These lineages are described as Nitrosospira lineage, Nitrosomonas marina lineage, Nitrosomonas oligotropha lineage, Nitrosomonas europaea/Ntrosococcus mobilis lineage, Nitrosomonas communis lineage, Nitrosomonas sp. Nm143 lineage and Nitrosomonas cryotolerans lineage (20). However, few data were available about the AOB composition in lake sediments with different ammonia status.

In this study, MPN technique was used to enumerate AOB and restriction fragment length polymorphism analysis (RFLP) based on amoA gene was used to identify its population structure at five sampling sites in sediments of a Chinese shallow eutrophic urban lake (Lake Yuehu). Additionally, the ammonium concentrations in interstitial water and the contents of organic matter (OM) in sediments were also detected. The aims of this study are (1) to determine the abundance and diversity of $\mathrm{AOB}$ in the eutrophic shallow lakes, and (2) to extend our understanding of AOB species occurred in sediments of freshwater lake with different ammonium status.

\section{MATERIALS AND METHODS}

\section{Study lakes and sampling sites}

Lake Yuehu $\left(114^{\circ} 14^{\prime} \sim 114^{\circ} 15^{\prime} \mathrm{E}, 30^{\circ} 33^{\prime} \mathrm{N}, 0.66 \mathrm{~km}^{2}, 1.2\right.$ $m$ mean depth), is a shallow eutrophic lake located in Wuhan City, Hubei Province. Due to the discharge of vast untreated domestic sewage in the past decades, the contents of organic matter (84.56-158.48 $\left.\mathrm{g} \mathrm{kg}^{-1}\right)$, TP (2.23-3.61 $\left.\mathrm{g} \mathrm{kg}^{-1}\right)$ and $\mathrm{TN}$ (3.72-5.84 $\mathrm{g} \mathrm{kg}^{-1}$ ) were high in surface sediment (7). Here, surface sediments $(0-3 \mathrm{~cm})$ were sampled at five sites in March, 2007 (Fig. 1).

\section{Measurement of chemical parameters in interstitial water and sediment}

Interstitial water was obtained from sediment by centrifugation at $4000 \mathrm{rpm}$ for $20 \mathrm{~min}$, and then filtered through $0.45 \mu \mathrm{m}$ polycarbonate filter membranes. Ammonium concentration was determined by the indophenol-blue method with spectrophotometry (46). Sediments at each sampling site were oven-dried at $80{ }^{\circ} \mathrm{C}$ for 2 days and ignited in a muffle furnace at $550{ }^{\circ} \mathrm{C}$ for $3 \mathrm{~h}$ to determine the values of loss on ignition (LOI) (16). Sediment $\mathrm{pH}$ values were determined using PHS-3C numerical $\mathrm{pH}$ meters using a sediment-to-water ratio of 1:5 after shaking for $1 \mathrm{~h}$.

\section{MPN enumeration}

MPN enumeration was performed according to Matulewich et al (23). Serial 10-fold dilutions of the suspension were prepared in $1 \mathrm{mM}$ phosphate buffer solution $(\mathrm{pH} 7.2)$, and 1-ml portions were transferred to 5 replicate tubes per dilution with the designated MSF medium (23). Samples were incubated at $28 \pm 1{ }^{\circ} \mathrm{C}$ in the dark. After 6 weeks incubation, the AOB medium was examined by removing a 
Qiu, S. et al.

few drops to a spot plate depression with the Griess reagent. If the medium gave a strong reaction (dark red) compared with the uninoculated control, the tube was scored positive for
AOB. Counting the positive tubes and subsequent quantification could be made using a table (26).

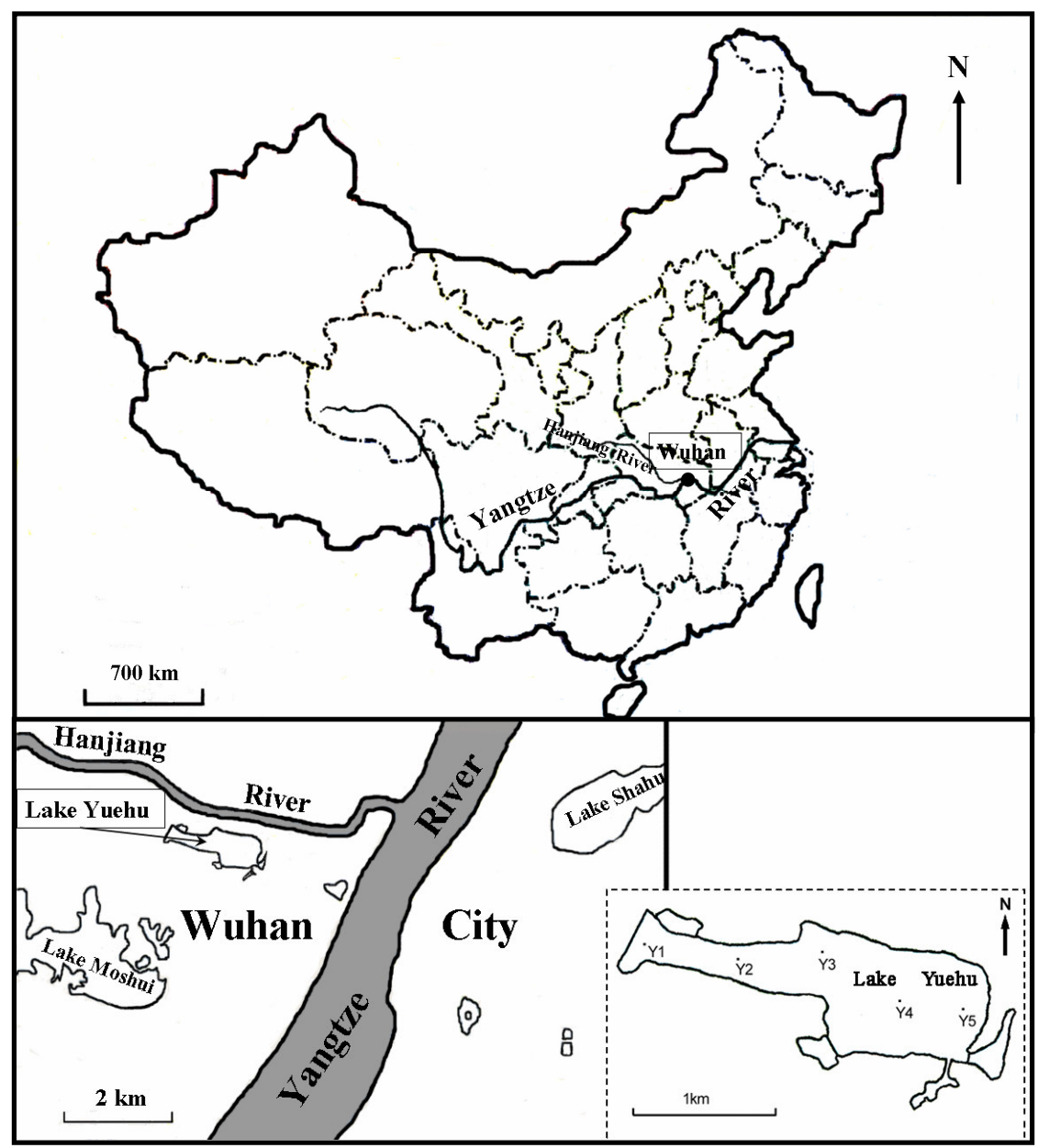

Figure 1. A location map of Wuhan City, China and that of Lake Yuehu. Y1-Y5 represent the five sampling sites.

DNA extraction from sediments and PCR of amoA fragment

The protocol of Zhou et al. (51) was used for DNA extraction from sediments at the five sites. PCR amplification of a 491-bp fragment of the amoA gene was carried out as described by Rotthauwe et al. (34) by using the $a m o A-1 \mathrm{~F}$ and amoA-2R primer with a DNA thermocycler (model PTC-200, Bio-Rad, USA).

\section{RFLP analysis of amoA gene and sequencing}

Five clone libraries were constructed for the five sites. The amplified amoA PCR fragments were excised from the agarose gel, and purified with an agarose gel extraction kit (Doupson, China). The 491-bp amoA DNA fragments from the five sites were cloned into the pMD18-T vector (TaKaRa, Japan) according to the manufacturer's instructions, respectively. 100 clones from each library were randomly selected for further analysis. The cloned inserts were reamplified with amoA primers and then digested with the MspI enzyme (TaKaRa). Restriction patterns were analyzed after gel electrophoresis on $2 \%$ agarose gels. Clones representative of each restriction pattern were chosen for sequence analysis on a DNA Sequencer (model Prism 377, ABI, USA). 


\section{Phylogenetic analysis}

The sequences were aligned using ClustalX program. Phylogenetic analysis of representative sequences including three outgroups was performed to reconstruct bifurcating trees using neighbor-joining (NJ) and maximum-parsimony (MP) approaches using PAUP* 4.0b10 (40). For MP analysis, heuristic searches were performed using tree bisectionreconnection $(\mathrm{TBR})$ branch-swapping and 10 random sequence addition replicates. All sites were equally weighted and gaps were treated as missing characters. Support for recovered clades was measured using a non-parametric bootstrap analysis (13) with 1000 replicates. For NJ analysis, Modeltest 3.7 (30) was used to find the model of nucleotide evolution with AIC criterion. To assess statistical support for hypothesized clades, bootstrap analysis was performed with 1000 replicates for NJ analysis (under the GTR $+\mathrm{I}+\mathrm{G}$ model of evolution, $-\operatorname{lnL}=$ $8265.6465)$.

\section{Nucleotide sequence accession numbers}

The sequences determined in this study have been deposited in the GenBank database under accession numbers: FJ498909-FJ498961.

\section{RESULTS}

\section{Distributions of chemical parameters in interstitial water and sediment}

As shown in Table 1, among all the sampling sites, the $\mathrm{NH}_{4}{ }^{+}$concentration in interstitial water and the sediment LOI were the lowest at Site Y3 and the highest at SiteY5. These two variables were significantly related with each other $(P<0.01$; $r=0.989$ ). Moreover, $\mathrm{pH}$ values in sediments were similar.

\section{AOB abundance in sediment}

At all sampling sites, the MPN numbers of AOB were at a magnitude of $10^{5}$ cells $\mathrm{g}^{-1}$ dry weight (Table 1 ) and positively related to $\mathrm{NH}_{4}{ }^{+}$concentrations $(P<0.05 ; r=0.955)$.

Table 1. Some characteristics of sampling sites in Lake Yuehu in March $2007^{\mathrm{a}}$

\begin{tabular}{llllll}
\hline characteristics & Y1 & Y2 & Y3 & Y4 & Y5 \\
\hline $\mathrm{pH}$ of sediment & $7.65 \pm 0.03$ & $7.82 \pm 0.02$ & $7.80 \pm 0.01$ & $7.66 \pm 0.04$ & $7.64 \pm 0.07$ \\
$\mathrm{NH}_{4}{ }^{+}$in porewater & $8.169 \pm 0.146$ & $8.501 \pm 0.325$ & $5.819 \pm 0.107$ & $9.321 \pm 0.304$ & $10.740 \pm 0.615$ \\
$\left(\mathrm{mg} \mathrm{l}^{-1}\right)$ & & & & \\
$\mathrm{LOI}^{\mathrm{b}}$ & $0.082 \pm 0.000$ & $0.083 \pm 0.001$ & $0.063 \pm 0.001$ & $0.086 \pm 0.001$ & $0.095 \pm 0.000$ \\
$\begin{array}{l}\mathrm{AOB}^{\mathrm{c}} \text { numbers in } \\
\text { sediment }\left(\times 10^{5}\right.\end{array}$ & $1.14 \pm 0.50$ & $1.20 \pm 0.33$ & $1.07 \pm 0.25$ & $1.22 \pm 0.35$ & $1.24 \pm 0.35$ \\
$\begin{array}{l}\text { cells g } \\
\text { weight })\end{array}$ & & & & & \\
\hline
\end{tabular}

\section{AOB diversity in sediment}

The RFLP analysis for the sediment at all sampling sites gave 13 different restriction patterns (A-M) for total $500 \mathrm{amoA}$ clones. The former 4 patterns (A-D) were shared by the five sites (Fig. 2). The 8 patterns including 4 unique ones were found at Site Y5, the 6 patterns including 2 unique ones were found at Site Y1, Site Y2 and Site Y4 respectively, while only common patterns without unique ones were found at Site Y3 (Table 2). Thus, the diversity of amoA gene was greatest at Site
Y5. Restriction group A was the major component for all sites, accounting for $81 \%$ - $89 \%$ of 100 clones in each library (Table 2).

As shown in Fig. 3, the amoA fragments retrieved from the sediments at the five sampling sites belonged to four lineages: N. oligotropha \& ureae lineage, N. europaea/Nc. mobilis lineage, N. communis lineage and Nitrosospira lineage. Most restriction patterns including $\mathrm{A}, \mathrm{B}, \mathrm{E}, \mathrm{G}, \mathrm{H}, \mathrm{I}, \mathrm{J}, \mathrm{K}, \mathrm{L}, \mathrm{M}$ groups belonged to Nitrosomonas group, and the remaining $\mathrm{C}$, 
Qiu, S. et al.

D, F groups belonged to Nitrosospira lineage. According to phylogenetic tree and Table 2, from Site Y1 to Site Y5, the clones of Nitrosomonas group made up $92 \%-87 \%$ of the total analyzed clones, and the clones of Nitrosospira lineage represented 8\%-13\% (Fig. 4).
The restriction group A was the predominant member in libraries for all sites, and most of this group was affiliated with the $N$. oligotropha \& ureae lineage. Thus N. oligotropha \& ureae-like bacteria were the dominant AOB species in the sediment of Lake Yuehu.

Table 2. Numbers of restriction patterns in each site and percentages of analyzed clones in each restriction pattern in each library

\begin{tabular}{|c|c|c|c|c|c|c|c|c|c|c|c|c|c|c|}
\hline \multirow[t]{2}{*}{ Sites } & \multirow{2}{*}{$\begin{array}{l}\text { Numbers of } \\
\text { restriction } \\
\text { patterns }\end{array}$} & \multicolumn{13}{|c|}{$\begin{array}{c}\text { Percentages of analyzed clones in each restriction pattern } \\
\text { in } 100 \mathrm{amoA} \text { clones of each library }(\%)\end{array}$} \\
\hline & & $\mathbf{A}$ & B & C & D & $\mathbf{E}$ & $\mathbf{F}$ & $\mathbf{G}$ & $\mathbf{H}$ & I & $\mathbf{J}$ & $\mathbf{K}$ & $\mathbf{L}$ & $\mathbf{M}$ \\
\hline Y1 & 6 & 89 & 2 & 5 & 2 & & 1 & 1 & & & & & & \\
\hline Y2 & 6 & 88 & 1 & 5 & 4 & & & & & 1 & 1 & & & \\
\hline Y3 & 4 & 89 & 2 & 7 & 2 & & & & & & & & & \\
\hline Y4 & 6 & 87 & 1 & 3 & 7 & & 1 & & 1 & & & & & \\
\hline Y5 & 8 & 81 & 1 & 6 & 7 & 2 & & & & & & 1 & 1 & 1 \\
\hline
\end{tabular}

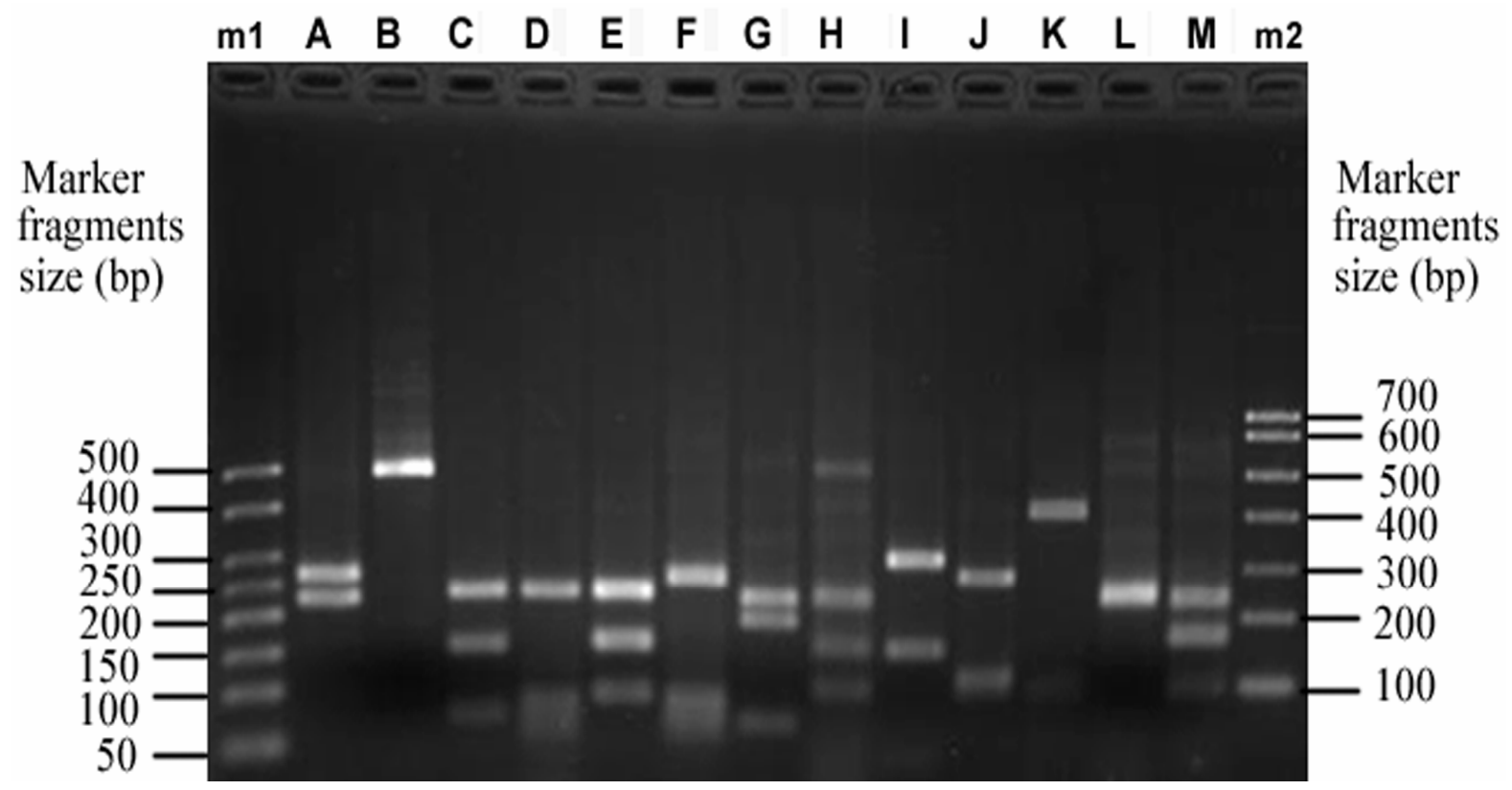

Figure 2. Gel with different $M s p$ I restriction patterns of analysed amoA clones from five sites in March 2007. Lanes A-M represent different restriction patterns of $a m o A$ gene; Lane $\mathrm{m} 1$ is 50bp ladder DNA (Transgen, China); Lane m2 is Marker 1 (Transgen, China). 


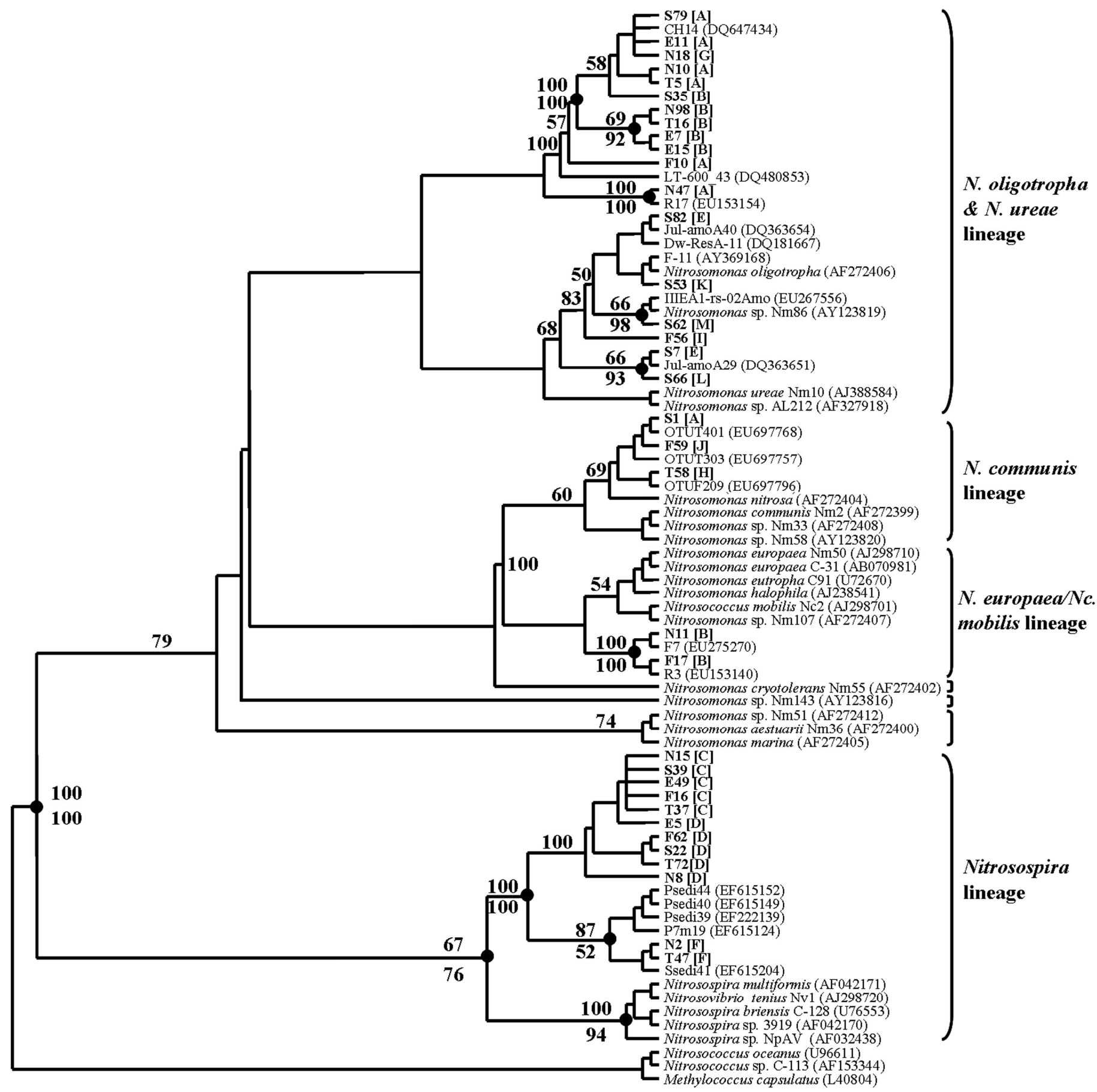

Figure 3. amoA-based MP tree of the betaproteobacterial AOB. The clone sequences reported in this study are depicted in bold. The tree was rooted with the pmoA sequence of Methylococcus capsulatus and the two amoA sequences of the gammaproteobacteria. The branch nodes supported by two phylogenetic analysis (MP and NJ) are indicated as solid circles. Numbers at branch nodes are bootstrap values obtained from MP analysis (above the branch) and NJ analysis (below the branch); only values greater than $50 \%$ and important to define the phylogenetically major lineages are indicated. Prefixes N, F, E, T and S of clone names represent Y1, Y2, Y3, Y4 and Y5, respectively. 


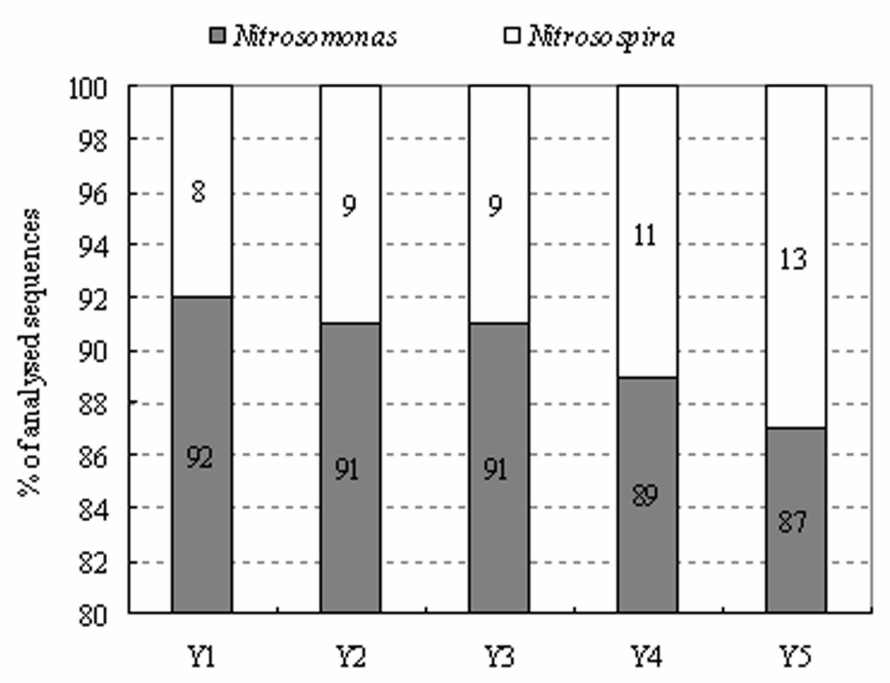

Figure 4. Proportions of analyzed clones belonging to Nitrosomonas and Nitrosospira in sediment AOB at the five sampling sites (Y1-Y5) in Lake Yuehu, respectively.

\section{DISCUSSION}

The spatial heterogeneity in $\mathrm{NH}_{4}^{+}$concentrations was found in interstitial water of Lake Yuehu, which was causatively linked to the sediment $\mathrm{OM}$ as evidenced by the significantly positive relation between the two variables (Table 1). In fact, potential $\mathrm{N}$ mineralization was positively correlated with the OM content (45). What is more, the most important impact of high concentration of $\mathrm{OM}$ is its contribution of additional oxygen demand (8) leading to the anaerobic condition in sediment, under which the rate of $\mathrm{NH}_{4}^{+}$releasing in the interface between water and sediment was 2-8 times higher than that at aerobic condition (12).

The AOB numbers were significantly proportional to the $\mathrm{NH}_{4}{ }^{+}$concentrations in interstitial water $(P<0.05 ; r=0.955)$, which was in agreement with other studies $(28,48)$. Interestingly, the numbers of restriction pattern were also positively correlated with $\mathrm{NH}_{4}{ }^{+}$concentrations in interstitial water $(P<0.01 ; r=0.966)$ as well. In details, the clones were clustered in 8 different restriction patterns at Site Y5 with the highest ammonium concentration, but, only 4 different patterns were found at site Y3 with the lowest ammonium concentration. All the remaining sampling sites gave 6 patterns.
It means that the different $\mathrm{NH}_{4}{ }^{+}$concentrations could shape the population structure of $\mathrm{AOB}$ in nature, which held true in various environments $(6,14,21,47)$.

In freshwater environments, the $N$. oligotropha \& ureaelike bacteria are generally the predominant AOB group, as evidenced by repeated isolation of members of this lineage from high MPN dilutions $(18,19,37)$ and molecular data including $16 \mathrm{~S}$ rDNA and $\operatorname{amoA}(5,21,32,36,50)$. Our result strengthened this conclusion. This lineage that well adapts to low ammonium concentrations can grow in various environments (2, 3). Moreover, isolates of this lineage (e.g., $N$. oligotropha, N. ureae, Nitrosomonas sp. AL212, etc.) are inhibited at high ammonium concentrations (exceeding 10 $\mathrm{mM})(4,35,37,39)$. Therefore, the ammonium concentrations in Lake Yuehu, ranging from $0.32 \mathrm{mM}$ to $0.60 \mathrm{mM}$, appeared to favor their growth.

The $N$. europaea/Nc. mobilis lineage is always dominant in waster-water treantment plants (WWTP) $(9,17,21)$, since its growth requires high ammonium concentrations. While, the ammonium concentration in Lake Yuehu was not high enough to support its growth, so the small numbers (2 amoA sequences) of total 500 clones were affiliated with this lineage, which is assumed to be derived from effluent discharge.

The $N$. communis lineage comprises the $N$. communis sublineage and $N$. nitrosa sublineage. The former prefers agricultural soils, while the latter is commonly distributed in more or less eutrophicated freshwater (20). From the phylogenetic tree, 3 clones (S1, F59, T58) in Lake Yuehu belonged to the $N$. nitrosa subgroup. Noticeably, they were retrieved from diverse environments like WWTP (10), activated sludge (29), freshwater estuary (5), soil (27), showing the ecological versatility.

The clones of the Nitrosospira lineage represented only $8 \%-13 \%$ of the total analyzed clones, probably due to the conditions in Lake Yuehu unsuitable for growth of these species that prefer terrestrial habitats (20).

Conclusively, this study revealed the abundance and diversity of sediment $\mathrm{AOB}$ and their significant relationships with ammonium status in a Chinese shallow eutrophic lake. 


\section{ACKNOWLEDGEMENTS}

This work was supported by the the National Basic Research Program of China (2008CB418005) the grant (KZCX2-YW426) from the Chinese Academy of Sciences and the funding (40730528) from the National Science Foundation of China.

\section{REFERENCES}

1. Belser, L.W.; Schmidt, E.L. (1978). Diversity in the ammonia-oxidizing nitrifier population of a soil. Appl. Environ. Microbiol., 36, 584-588.

2. Bollmann, A.; Laanbroek, H.J. (2001). Continuous culture enrichments of ammonia-oxidizing bacteria at low ammonium concentrations. FEMS Microbiol. Ecol., 1279, 1-11.

3. Bollmann, A.; Bär-Gilissen, M.J.; Laanbroek, H.J. (2002). Growth at low ammonium concentrations and starvation response as potential factors involved in niche differentiation among ammonia-oxidizing bacteria. Appl. Environ. Microbiol., 68, 4751-4757.

4. Burrell, P.C.; Phalen, C.M.; Hovanec, T.A. (2001). Identification of bacteria responsible for ammonia oxidation in freshwater aquaria. Appl. Environ. Microbiol., 67, 5791-5800.

5. Cébron, A.; Berthe, T.; Garnier, J. (2003). Nitrification and nitrifying bacteria in the lower Seine River and estuary (France). Appl. Environ. Microbiol., 69, 7091-7100.

6. Ceccherini, M.T.; Castaldini, M.; Piovanelli, C.; Hasting, R.C.; McCarthy, A.J.; Bazzicalupo, M.; Miclaus, N. (1998). Effects of swine manure fertilization on autotrophic ammonia oxidizing bacteria in soil. Appl. Soil Ecol., 7, 149-157.

7. Chen, F.; Xia, Z.Y.; Song, C.L.; Li, J.Q.; Zhou, Y.Y. (2007) Relationship between organic matter in sediments and internal nutrient loadings in shallow lakes in Hubei Province of China. Acta Hydrobiologica Sin., 31, 467-472.

8. Chen, S.; Ling, J.; Jean-Paul, B. (2006). Nitrification kinetics of biofilm as affected by water quality factors. Aquacult. Eng., 34, 179-197.

9. Daims, H.; Purkhold, U.; Bjerrum, L.; Arnold, E.; Wilderer, P.A.; Wagner, M. (2001). Nitrification in sequencing biofilm batch reactors: lessons from molecular approaches. Water Sci. Tech., 43, 9-18.

10. Dionisi, H.M.; Layton, A.C.; Harms, G.; Gregory, I.R.; Robinson, K.G.; Sayler, G.S. (2002). Quantification of Nitrosomonas oligotropha-like ammonia-oxidizing bacteria and Nitrospira spp. from fullscale wastewater treatment plants by competitive PCR. Appl. Environ. Microbiol., 68, 245-253.

11. Effler, S.W.; Brooks, C.M.; Whitehead, K.A. (1996) Domestic waste inputs of nitrogen and phosphorus to Onondaga Lake, and water quality implications. Lake Reserv. Manag., 12, 127-140.

12. Fan, C.X.; Aizaki, M. (1997). Effects of aerobic and anaerobic conditions on exchange of nitrogen and phosphorus across sediment-water interface in Lake Kasumigaura. J. Lake Sci., 9(4), 337-342.

13. Felsenstein, J.P. (1985). Conwdence limits on phylogenies: an approach using the bootstrap. Evolution, 39, 783-791.

14. Hastings, R.C.; Ceccherini, M.T.; Nerino, M.; Saunders, J.R.; Bazzicalupo, M.; McCarthy, A.J. (1997). Direct molecular biological analysis of ammonia oxidising bacteria populations in cultivated soil plots treated with swine manure. FEMS Microbiol. Ecol., 23, 45-54.

15. Head, I.M.; Hiorns, W.D.; Embley, T.M.; McCarthy, A.J.; Saunders, J.R. (1993). The phylogeny of autotrophic ammonia-oxidizing bacteria as determined by analysis of $16 \mathrm{~S}$ ribosomal RNA gene sequences. J. Gen. Microbiol., 139, 1147-1153.

16. Hirabayashi, K.; Hanazato, T.; Nakamoto, N. (2003). Population dynamics of Propsilocerus akamusi and Chironomus plumosus (Diptera: Chironomidae) in Lake Suwa in relation to changes in the lake's environment. Hydrobiologia, 506-509, 381-388.

17. Juretschko, S.; Timmermann, G.; Schmid, M.; Schleifer, K.H.; Pommerening-Roser, A.; Koops, H.P.; Wagner, M. (1998). Combined molecular and conventional analyses of nitrifying bacterium diversity in activated sludge: Nitrosococcus mobilis and Nitrospira-like bacteria as dominant populations. Appl. Environ. Microbiol., 64, 3042-3051.

18. Koops, H.P.; Harms, H. (1985). Deoxyribonucleic acid homologies among 96 strains of ammonia-oxidizing bacteria. Arch. Microbiol., 141, 214-218.

19. Koops, H.P.; Pommerening-Röser, A. (2001). Distribution and ecophysiology of the nitrifying bacteria emphasizing cultured species. FEMS Microbiol. Ecol., 37, 1-9.

20. Koops, H.P.; Purkhold, U.; Pommerening-Röser, A.; Timmermann, G.; Wagner, M. (2006). The lithoautotrophic ammonia-oxidizing bacteria. In: Dworkin, M., Falkow, S., Rosenberg, E., Schleifer, K.H., Stackebrandt, E. (eds). The Prokaryotes Vol.5. Springer-Verlag, New York, USA, p. 778-811.

21. Limpiyakorn, T.; Kurisu, F.; Sakamoto, Y.; Yagi, O. (2007). Effects of ammonium and nitrite on communities and populations of ammoniaoxidizing bacteria in laboratory-scale continous-flow reactors. FEMS Microbiol. Ecol., 60, 501-512.

22. Macrae, A. (2000). The use of $16 \mathrm{~S}$ rDNA methods in soil microbiology ecology. Braz. J. Microbiol., 31, 77-82.

23. Matulewich, V.A.; Strom, P.F.; Finstein, M.S. (1975). Length of incubation for enumerating nitrifying bacteria present in various environments. Appl. Microbiol., 29, 265-268.

24. McTavish, H.; Fuchs, J.A.; Hooper, A.B. (1993). Sequence of the gene coding for ammonia monooxygenase in Nitrosmonas europaea. J. Bacteriol., 175, 2436-2444.

25. Mendum, T.A.; Sockett, R.E.; Hirsch, P.R. (1999). Use of molecular and isotopic techniques to monitor the response of autotrophic ammoniaoxidizing populations of the $\beta$ subdivision of the class Proteobacteria in arable soils to nitrogen fertilizer. Appl. Environ. Microbiol., 65, 41554162 .

26. Meynell, G.G.; Meynell, E. (1965). Theory and practice of experimental 
bacteriology. Cambridge University Press, Cambridge.

27. Nicolaisen, M.H.; Ramsing, N.B. (2002). Denaturing gradient gel electrophoresis (DGGE) approaches to study the diversity of ammoniaoxidizing bacteria. J. Microbiol. Meth., 50, 189-203.

28. Okano, Y.; Hristova, K.R.; Leutenegger, C.M.; Jackson, L.E.; Denison, R.F.; Gebreyesus, B.; Lebauer, D.; Scow, K.M. (2004). Application of real-time PCR to study effects of ammonium on population size of ammonia-oxidizing bacteria in soil. Appl. Environ. Microbiol., 70(2), 1008-1016.

29. Park, H.D.; Noguera, D.R. (2004). Evaluating the effect of dissolved oxygen on ammonia-oxidizing bacterial communities in activated sludge. Water Res., 38, 3275-3286.

30. Posada, D.; Crandall, K.A. (1998). MODELTEST: testing the model of DNA substitution. Bioinformatics, 14: 817-818.

31. Prosser, J.I. (1989). Autotrophic nitrification in bacteria. Adv. Microb. Physiol., 30, 125-181.

32. Qin, Y.Y.; Zhang, X.W.; Ren, H.Q.; Li, D.T.; Yang, H. (2008). Population dynamics of ammonia-oxidizing bacteria in an aerated submerged biofilm reactor for micropolluted raw water pretreatment. Appl. Microbiol. Biotechnol., 79, 135-145.

33. Qiu, S.L.; Zhou, Y.Y. (2008). Effect of different media on MPN estimation of ammonia-oxidizing bacteria in lakes. Microbiology, 35(10), 1668-1673.

34. Rotthauwe, J.H.; Witzel, K.P.; Liesack, W. (1997). The ammonia monooxygenase structural gene $a m o A$ as a functional marker: molecular fine-scale analysis of natural ammonia-oxidizing populations. Appl. Environ. Microbiol., 63, 4704-4712.

35. Regan, J.M.; Harrington, G.W.; Noguera; D.R. (2002). Ammonia- and nitrite-oxidizing bacterial communities in a pilot-scale chloraminated drinking water distribution system. Appl. Environ. Microbiol., 68, 73-81.

36. Speksnijder, A.G.C.L.; Kowalchuk, G.A.; Roest, K.; Laanbroek, H.J. (1998). Recovery of a Nitrosomonas-like 16S rDNA sequence group from freshwater habitats. Syst. Appl. Microbiol., 21, 321-330.

37. Stehr, G.; Bottcher, B.; Dittberner, P.; Rath, G.; Koops, H.P. (1995). The ammonia-oxidizing nitrifying population of the River Elbe estuary. FEMS Microbiol. Ecol., 17, 177-186.

38. Suwa, Y.; Imamura, Y.; Suzuki, T.; Tashiro, T.; Urushigawa, Y. (1994). Ammonia-oxidizing bacteria with different sensitivities to $\left(\mathrm{NH}_{4}\right)_{2} \mathrm{SO}_{4}$ in activated sludge. Water Res., 28, 1523-1532.

39. Suwa, Y.; Sumino, T.; Noto, K. (1997). Phylogenetic relationships of activated sludge isolates of ammonia oxidizers with different sensitivities to ammonium sulfate. J. Gen. Appl. Microbiol., 43, 373-379.
40. Swofford, D.L. (2003). PAUP*: Phylogenetic Analysis Using Parsimony (* and other methods), Version 4.0b10. Sinauer Associates, Sunderland, Massachusetts.

41. Teske, A.; Alm, E.; Regan, J.M.; Toze, S.; Rittmann, B.E.; Stahl, D.A. (1994). Evolutionary relationships among ammonia- and nitrite-oxidizing bacteria. J. Bacteriol., 176, 6623-6630.

42. Tigano, M.S.; Aljanabi, S.; Mello, S.C.M. (2003). Genetic variability of Brazilian Alternaria spp. isolates as revealed by RAPD analysis. Braz. J. Microbiol., 34, 117-119.

43. Urakawa, H.; Kurata, S.; Fujiwara, T; Kuroiwa, D.; Maki, H.; Kawabata, S.; Hiwatari, T.; Ando, H.; Kawai, T.; Watanabe, M.; Kohata, K. (2006). Characterization and quantification of ammonia-oxidizing bacteria in eutrophic coastal marine sediments using polyphasic molecular approachs and immunofluorescence staining. Environ. Microbiol., 8, 787-803.

44. Utåker, J.B.; Nes, I.F. (1998). A qualitative evaluation of the published oligonucleotides specific for the 16S rRNA gene sequences of ammonia oxidizing bacteria. Syst. Appl. Microbiol., 21, 72-88.

45. van Vliet, P.C.J.; van der Stelt, B.; Rietberg, P.I.; de Goede, R.G.M. (2007). Effects of organic matter content on earthworms and nitrogen mineralization in grassland soils. Eur. J. Soil. Biol., 43, S222-S229.

46. Verdouw, H.C.; VanEchteld, J.A.; Dekker, T. (1978). Ammonia determination based on indophenol formation with sodium salicylate. Water Res., 13, 399-402.

47. Whitby, C.B.; Saunders, J.R.; Rodriguez, J.; Pickup, R.W.; McCarthy, A.J. (1999). Phylogenetic differentiation of two closely related Nitrosomonas spp. that inhabit different sediment environments in an oligotrophic freshwater lake. Appl. Environ. Microbiol., 65, 4855-4862.

48. Whitby, C.B.; Saunders, J.R.; Pickup, R.W.; McCarthy, A.J. (2001). A comparison of ammonia-oxidizer populations in eutrophic and oligotrophic basins of a large freshwater lake. Anton. Leeuw. Int. J. G., $79,179-188$

49. Wu, S.K.; Xie, P.; Wang, S.B.; Zhou, Q. (2006). Changes in the patterns of inorganic nitrogen and TN/TP ratio and the associated mechanisms of biological regulation in the shallow lakes along the middle and lower reaches of the Yangtze River. Sci China (Ser D), 49(Suppl. I), 126-134.

50. Zhang, Y.; Ruan, X.H.; Op den Camp, H.J.M.; Smits, T.J.M.; Jetten, M.S.M.; Schmid, M.C. (2007). Diversity and abundance of aerobic and anaerobic ammonium-oxidizing bacteria in freshwater sediment of the Xinyi River (China). Environ. Microbiol., 9, 2375-2382.

51. Zhou, J.Z.; Bruns, M.A.; Tiedje, J.M. (1996). DNA recovery from soils and diverse composition. Appl. Environ. Microbiol., 62, 316-322. 